\author{
Piotr Jordan Śliwiński OFMCap ${ }^{1}$ \\ 0000-0002-2833-063X \\ Uniwersytet Jagieloński, Kraków
}

\title{
Personalistyczna zasada wychowania w Itinerarium mentis in Deum św. Bonawentury
}

W historii wychowania często bywało tak, że wybitni wychowawcy formułowali swe doświadczenia w znaczące dzieła poświęcone wychowaniu. Wystarczy przypomnieć sobie spuściznę Janusza Korczaka czy Celestyna Freineta. Zdarzała się też droga odwrotna - wybitni teoretycy, myśliciele próbowali swe koncepcje przenieść na grunt wychowania, formowania - tak działo się w życiu niejednego filozofa - żeby wspomnieć Platona, Arystotelesa czy też Kanta bądź Hegla.Zdarzało się, że teoretycy - jak filozofowie greccy - sami stawali się wychowawcami, bywało jak w przypadku myślicieli nowożytnych, że co najwyżej przekazywali wiedzę, a przy okazji zajmowali się teoretycznie tematami związanymi z wychowaniem.

1 Piotr Jordan Śliwiński OFMCap - ur. 1963 roku, mgr teologii (PAT, Kraków, 1992), dr filozofii (PUG, Roma, 1997), wykładowca Uniwersytetu Jagiellońskiego (Katedra Lingwistyki Komputerowej) i kapucyńskiego WSD w Krakowie, członek ekipy Szkoły dla Spowiedników. Autor publikacji z zakresu filozofii, antropologii kultury i nowej religijności. Wybrane publikacje: Zagubiony i odnaleziony wnie-miejscu, w: Kondycja człowieka współczesnego (2006); Internet jako encyklopedia, w: Komputer - człowiek - prawo (2007); Grzechy w kratkę (2008); Reguły życia. W rodzinie i zakonie (2009); Człowiek do przepracowania, w: Praca i bezczynność (2009); Od city do Gombrowicza czyli o nie-miejscu pieściwym, w: Gombrowicz nasz współczesny (2010); Spowiedź nie musi bardzo boleć (2016). E-mail: piotrjordan.sliwinski@uj.edu.pl. 


\section{Kontekst}

\subsection{Sytuacja Autora}

Ze świętym Bonawenturą z Bagnoregio było trochę inaczej². Musiał przerwać błyskotliwą karierę naukową, aby podjąć trudną funkcję generała Zakonu Braci Mniejszych. Chociaż jego nominacji na magistra (czyli profesora) papież zażądał w 1256 roku, to na skutek sporów na Uniwersytecie Paryskim otrzymał katedrę dopiero w październiku 1257 roku, gdy od pół roku był już generałem Zakonu Braci Mniejszych. Wybór młodego naukowca na przełożonego całego zakonu franciszkańskiego miał dla niego zasadnicze konsekwencje. Nie tylko oznaczał w praktyce zaprzestanie pracy badawczej i dydaktycznej na uniwersytecie, ale także zderzenie z całym szeregiem problemów związanych z życiem wspólnoty Braci Mniejszych, która po śmierci w 1226 roku swego założyciela świętego Franciszka przeżywała różnorakie trudności związane z realizacją jego dziedzictwa. Konfrontacja z millenaryzmem Joachima de Fiore, spór o sposób rozumienia świętego Franciszka, próby coraz bardziej precyzyjnego wyjaśnienia Reguły i sposobu życia braci mniejszych, gwałtowny rozwój liczebny oraz ekspansja terytorialna młodego zakonu - to tylko najważniejsze problemy, wobec których musiał stanąć młody generał. Nie były one bynajmniej błahe - np. doktryna Joachima de Fiore zawierała wątki niebezpiecznie zbliżające się do myślenia heterodoksyjnego, w związku z tym poprzednik Bonawentury na urzędzie Jan z Parmy stanął przed sądem Inkwizycji podejrzany o herezję. Bonawentura, osobiście przekonany o świętości Jana musiał być jednak - zgodnie z ówczesnym prawem - przewodniczącym trybunału inkwizycyjnego. Proces doprowadził do uniewinnienia Jana z Parmy, ale był zapowiedzią problemów, z którymi będzie musiał się zderzyć we własnej wspólnocie zakonnej nowy generał Zakonu Braci Mniejszych.

2 Informacje biograficzne na podstawie: L. Veuthey, Filozofia chrześcijańska św. Bonawentury, tłum. R. I. Zieliński, Niepokalanów 1996, s. 13-15; M. Prodi - M. Rossini, Introduzione, w: Bonaventura da Bagnoregio, Itinerario della mente verso Dio, Milano 1994, 5-62. 


\subsection{Miejsce}

Bonawentura udaje się na górę Alwernię (dziś La Verna). Miejsce to sławne i znane dla każdego franciszkanina. Otrzymał je w prezencie Biedaczyna z Asyżu, aby mógł tam znaleźć w samotności czas na wyłączne zajmowanie się modlitwą. Tam przebywał na modlitwie i tam w 1224 roku otrzymał stygmaty. Święty Franciszek dostał tę górę w darze od Orlando z Chiusi w Casentino, szlachcica, posiadacza ziemskiego. Jej wysokość to około $1200 \mathrm{~m}$ nad poziomem morza, a znajduje się w Toskanii, tworząc samotny masyw. Po śmierci Biedaczyny z Asyża góra ta stała się symbolem eremityzmu franciszkańskiego. Przebywali na niej obok Bonawentury, brat Idzi czy Hubertyn z Casale i inni franciszkanie szukający w tym miejscu naznaczonym Franciszkowym czuwaniem szczególnej przestrzeni modlitwy i medytacji. Dziś na górze mieści się nowicjacki klasztor Braci Mniejszych oraz sanktuarium, które odwiedzają zwłaszcza franciszkanie z całego świata ${ }^{3}$.

\subsection{Itinerarium jako zapis medytacji}

Dziełko Itinerarium mentis in Deum napisał św. Bonawentura jako rodzaj przewodnika duchowego, albo raczej podręcznika duchowego dla Braci Mniejszych ${ }^{4}$. Medytacja prowadzona na Alwerni wiodła do świętego Franciszka w scenie stygmatyzacji, a następnie przy wykorzystaniu typowej dla Doktora Serafickiego analizy symbolicznej, była odczytywaniem symboliki sześciu skrzydeł serafina. W postaci tego znanego z Biblii czystego ducha miał się ukazać Biedaczynie z Asyża sam Chrystus. Dziełko miało być w zamierzeniu autora rodzajem przewodnika, podręcznika na drodze naśladowania świętego Franciszka. Bonawentura rozpoznaje jako symbol sześć skrzydeł serafina, które odczytuje jako kolejne etapy w drodze duszy ku Bogu. Są to: zmysły zewnętrzne, wyobraźnia, rozum,

3 M. B. Barfucci, Verna, w: Dizionario francescano, a cura di E. Caroli, Padova 1995, s. 2187-2203.

4 Korzystam z włoskiej edycji dwujęzycznej. Zawiera ona tekst łaciński z wydania typicznego Quaracchi: Bonaventura de Balneoregio, Itinerarium mentis in Deum, w: Opuscoli teologici 1, Roma 1993, s. 499-573 (cyt. dalej: Itinerarium mentis in Deum). 
intelekt, inteligencja i jako szczyt władz poznawczych syndereza ${ }^{5}$. Poszczególne władze poznawcze odpowiadają podziałowi wiedzy ludzkiej prezentowanego przez Doktora Serafickiego w innych dziełach. Itinerarium choć w zamierzeniu autora miało być rodzajem podręcznika dla każdego brata mniejszego było jednak dziełem niełatwym. Choć z racji autorytetu, jakim cieszył się Bonawentura wśród współbraci, nie było ono kontestowane, to jednak dziełko było na tyle trudne, że jego recepcja wśród braci była ograniczona. Z pewnością jest możliwe jego zastosowanie jako podręcznika, czy duchowego przewodnika dla kogoś żyjącego czy inspirującego się duchowością franciszkańską współcześnie. Można jednak sądzić, że da się wyprowadzić z Itinerarium przynajmniej parę propozycji przydatnych we współczesnej formacji franciszkańskiej. W tym szkicu skupimy się na pewnych wskazaniach metodologicznych dla takowej formacji, które tworzą ramę rozwoju franciszkanina, pomijając konkretne treści i postawy przyjmowane w poszczególnych etapach formacji.

\section{Hermeneutyka personalistyczna}

Święty Bonawentura podejmuje w Itinerarium bardzo ciekawą metodę interpretacji. Nie rezygnując z charakterystycznej dla siebie metody symbolicznej - jako symbol wokół którego buduje rozważania dziełka wybiera serafina, w postaci którego miał się Franciszkowi objawić Chrystus - Bonawentura interpretuje doświadczenie świętego Franciszka. Doświadczenie osobowego spotkania Biedaczyny z Asyżu z Chrystusem Ukrzyżowanym objawiającym się w postaci serafina staje się drogowskazem dla franciszkanów, którzy mają rozważać życie swego założyciela, próbować go naśladować. Można zatem powiedzieć o odczytywaniu zarówno życia poszczególnego franciszkanina, jak i całej wspólnoty franciszkańskiej w perspektywie doświadczenia świętego Franciszka. Jego życie, doświadczenie, droga do zjednoczenia z Bogiem są wyznacznikiem sposobu życia brata mniejszego. Naśladowanie Franciszka jest realizacją

\footnotetext{
5 Por. Itinerarium mentis in Deum V.
} 
Ewangelii, a zatem doskonałą formą naśladowania Chrystusa. Upodabnianie się do Założyciela Zakonu Braci Mniejszych będzie polegało na odwzorowywaniu w życiu brata mniejszego cech relacji Franciszkowej do Chrystusa, a w konsekwencji także cech jego relacji do Boga i świata stworzeń. Wdrażanie do takiej personalistycznej, dialogicznej zasady formacji zakładało rozważanie nie tylko treści nauczania Franciszka, pozostałych w jego pismach i pierwszych biografiach, ale poznawanie również jego postaw i wyborów w konkretnych sytuacjach życiowych. Można się doszukiwać fundamentu takiej propozycji w egzemplaryzmie bonawenturiańskim, zaczerpniętym od świętego Augustyna, lecz nawet bez tego fundamentu propozycja takiej - można by dzisiejszym językiem określić - hermeneutyki personalistycznej wydaje się interesująca ${ }^{6}$.

Bez wątpienia bonawenturiańska prezentacja życia świętego Franciszka nie jest wolna od elementów polemicznych. Młodemu Zakonowi Braci Mniejszych grożą różne napięcia związane z wielością interpretacji życia Biedaczyny z Asyżu, które w póżniejszej historii zakonu doprowadziły do podziałów. Bonawentura próbuje im zapobiec, pisząc życiorysy Świętego Założyciela i doprowadzając na kapitule generalnej 1266 roku do nakazu zniszczenia wszystkich innych życiorysów Biedaczyny z Asyżu?

\section{Kontuicja jako metoda medytacji franciszkańskiej}

W egzemplaryzmie, zaczerpniętym od św. Augustyna, ma też swoje spekulatywne oparcie metoda modlitwy, medytacji proponowana przez Bonawenturę. Można w niej odnaleźć, obok inspiracji platońskiej, również wpływ doświadczenia św. Franciszka, zwłaszcza tego, które zawarł w Pieśni słonecznej. Pochwała stworzeń nie wynikała u niego - jak chcą niektórzy ze współczesnych interpretatorów - jedynie z estetycznej fascynacji lub ekologicznej wrażliwości, ale z odczytania ich jako znaków

6 A. Nguyen Van Si, Seguire e imitare Cristo secondo san Bonaventura, tłum. P. Simpliciano Olgiati, Milano 1995, s. 30n.

7 L. Iriarte, Historia franciszkanizmu, tłum. S. Kafel i in., Kraków 1998, s. 64. 
wskazujących na Stwórcę - Boga. Polegała ona na próbie odczytania sensu i znaczenia stworzeń poprzez Boga, była próbą odkrycia Bożego zamysłu w danym konkretnym bycie. Każda rzecz była stworzona według wzoru, którym były idee w umyśle Bożym, ostatecznie zaś odczytywanie sensu każdego stworzenia przez odniesienie do Chrystusa. Taka prosta metoda intuicyjno-medytacyjnego poznania została przez Bonawenturę nazwana kontuicją (łac. contuitio) ${ }^{8}$. Medytując w taki sposób, można odkryć różne elementy otaczającego świata i ich głęboki sens, znaczenie, jakie nadał im Stwórca, które powinny być przez człowieka szanowane. Można tu mówić o uczeniu się posłuszeństwa wobec rzeczy, używając ich i je wartościując zgodnie z zamysłem Stwórcy. Na przykład nóż służy do krojenia pokarmu, a nie do zabijania czy ranienia drugiego człowieka. Odkrywanie znaczenia poszczególnych przedmiotów, bytów w zamyśle Bożym, choć niedoskonałe, prowadzi jednak do odpowiedniej hierarchizacji wiedzy ${ }^{9}$.

\section{Gmach wiedzy}

Bonawentura we wszystkich dziełach, również w Itinerarium, podkreśla jedność poznania i konieczność uzupełniania poznania naturalnego, przez poznanie wynikające z wiary. Prowadzi to nieuchronnie do traktowania poznania naturalnego (rozumowego), naukowego czy filozoficznego jako ważnego, ale będącego jedynie stopniem prowadzącym do pełnego poznania, które osiągane dzięki łasce Bożej, uwieńczone jest najwyższym poznaniem, jakie człowiek może osiągnąć po śmierci w niebie. Doktor Seraficki odmiennie od św. Tomasza z Akwinu sądzi, że każde poznanie, jeśli ma być pełne, musi być dopełnione przez poznanie teologiczne i mistyczne ${ }^{10}$. Bonawentura rozumie i usprawiedliwia sytuację i poglądy filozofów greckich, zwłaszcza Arystotelesa, stwierdzając, że nie s. $188-200$.

8 C. Bérubé, Dela philosophie a la sagesse chez saint Bonaventure et Roger Bacon, Roma 1976,

9 Itinerarium mentis in Deum 2, 9.

10 S. Swieżawski, Święty Tomasz i św. Bonawentura dziś, w: S. Swieżawski, Istnienie i tajemnica, Lublin 1993, 45-59. 
znając objawienia chrześcijańskiego zatrzymał się w swych poglądach jedynie na poznaniu intelektualnym. Sądzi jednak, że po przyjściu Chrystusa na ziemię i głoszeniu Ewangelii, nie można zatrzymać się jedynie na prawdach uznawanych jedynie rozumowo, ale należy dopełnić poznanie intelektualne tym, które płynie z wiary, a zwłaszcza poznaniem danym przez Biblię oraz uzyskanym przez kontemplację. W poglądach Bonawentury na tę kwestię pojawia się silna nuta polemiczna wobec poglądów Siegiera z Brabantu, będącego pod silnym wpływem Aweroe$\mathrm{sa}^{11}$. Filozof ten głosił konieczność dostosowania wszelkich prawd, także teologicznych, do zasad rozumowych, co w konsekwencji prowadziło do zamiany wiary religijnej w rodzaj jedynie systemu filozoficznego.

\section{Podsumowanie}

Bonawenturiańskie Itinerarium mentis in Deum ciągle może być inspiracją we współczesnej formacji franciszkańskiej i chrześcijańskiej. Domaga się jednak dociekliwej, pogłębionej analizy, która pozwoli z trudno przyswajalnego dzisiaj symbolizmu wyłowić interesujące i ciągle inspirujące kierunki oraz metody, które nadają się we współczesnej formacji, zwłaszcza w perspektywie budowania spójnego franciszkańskiego rozumienia i przeżywania relacji do świata, drugiego człowieka i Boga.

11 F. Van Steenberghen, Maître Siger de Brabant, Paris 1977. 


\section{Summary}

\section{Personalistyczna zasada wychowania w Itinerarium mentis in Deum świętego Bonawentury}

Itinerarium mentis in Deum to dziełko świętego Bonawentury napisane jako podręcznik dla formacji franciszkanów. Jej zasadniczym rysem jest naśladowanie świętego Franciszka z Asyżu. Bonawentura medytując życie Biedaczyny, proponuje formy jego naśladowania. Posługuje się przy tym językiem filozoficzno-teologicznym, a co za tymidzie dokonuje ciekawej interpretacji życia i osoby Świętego z Asyżu. Artykuł analizuje bliżej: proponowaną koncepcję hierarchii wiedzy oraz proponowany sposób medytacji jako dwa ciekawe przykłady takiej personalistycznie zorientowanej formacji.

Słowa kluczowe: Itinerarium mentis in Deum, personalizm, formacja

The personalistic principle of education in Itinerarium Mentis in Deum by Saint Bonaventure

Saint Bonaventure's Itinerarium mentis in Deum is written as a textbook on the formation of Franciscans, its basic tenet being imitation of Saint Francis of Assisi. Pondering over Francis' life, Bonaventure, using the language of philosophy and theology, suggests forms of imitating the saint and thus offers an interesting interpretation of Francis and his life. The paper focuses on the suggested concept of a hierarchy of knowledge and the suggested method of meditating as two valuable examples of that personalistic formation.

Keywords: Itinerarium mentis in Deum, personalism, formation

\section{Bibliografia}

Barfucci M. B., Verna, w: Dizionario francescano, red. E. Caroli, Padova 1995, s. 2187-2203.

Bérubé C., De la philosophie a la sagesse chez saint Bonaventure et Roger Bacon, Roma 1976.

Bonaventura de Balneoregio, Itinerarium mentis in Deum, w: Bonaventura de Balneoregio, Opuscoli teologici 1, Roma 1993, s. 499-573.

Iriarte L., Historia franciszkanizmu, tłum. S. Kafel i in., Kraków 1998.

Nguyen Van Si A., Seguire e imitare Cristo secondo san Bonaventura, tłum. P. Simpliciano Olgiati, Milano 1995.

Prodi M. -Rossini M., Introduzione, w: Bonaventura da Bagnoregio, Itinerario della mente verso Dio, Milano 1994, 5-62. 
Scapin P., L'Itinerarium mentis in Deum e il De Primo Principio. Convergenze e divergenze nell'approcio razionale di Dio, w: San Bonaventura maestro di vita francescana e di sapienza cristiana, t. 2, red. A. Pomrei, Roma 1976, 21-40.

Swieżawski S., Święty Tomasz i św. Bonawentura dziś, w: S. Swieżawski, Istnienie i tajemnica, Lublin 1993, s. 45-59.

Van Steenberghen F., Maître Siger de Brabant, Paris 1977.

Veuthey L., Filozofia chrześcijańska św. Bonawentury, tłum. R. I. Zieliński, Niepokalanów 1996. 